\title{
Scale for Measuring Phubbing in Peruvian University Students: Adaptation, Validation and Results of Its Application
}

\author{
José Manuel Ríos Ariza ${ }^{1}$, Antonio Matas-Terrón² ${ }^{(D)}$, Rocío del Pilar Rumiche Chávarry ${ }^{3}$ ab and \\ Gerardo Raúl Chunga Chinguel ${ }^{3}$ (I)
}

${ }^{1}$ U.D. of Research Methods, University of Málaga, Spain

${ }^{2}$ Department of Didactics and School Organisation, University of Málaga, Spain

${ }^{3}$ Universidad Católica Santo Toribio de Mogrovejo, Peru

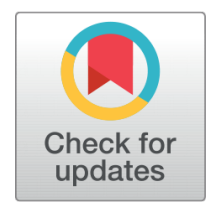

Received 2020-05-26
Revised 2020-08-03
Accepted 2021-02-16
Published 2021-07-15

Corresponding Author José Manuel Ríos Ariza, jmrios@uma.es

Facultad de Ciencias de la Educación, Campus de Teatinos. 29010 - Málaga, Spain

DOI https://doi.org/10.7821/ naer.2021.7.606

Pages: 175-189

Distributed under

Creative Commons CC BY 4.0

Copyright: (C) The Author(s)

\section{OPEN ACCESS}

\section{ABSTRACT}

Phubbing is defined as ignoring people with whom you have a face-to-face relationship to attend to smartphones. The phenomenon of phubbing particularly affects the teenage and young segments of the population. The main problem lies in the impact it has on individuals' social relationship. A lack of validated instruments to diagnose this phenomenon has been observed amongst the Spanish-speaking youth. The objective pursued with this research was to analyse the structural validity and reliability of the Spanish scale in a sample of 454 Peruvian university students. A reliability study was carried out following Cronbach and McDonald, complemented with an exploratory and confirmatory factor analysis. The results show good reliability and validity values. Finally, some aspects associated with users' profiles in relation to the scale were discussed too. A need exists to have adapted instruments which permit to measure emerging social threats such as phubbing, so that risk profiles can be identified and for us to be able to act in time. Most of the students surveyed regularly engaged in phubbing, and a significant percentage of them had personal and social problems because of this, including lack of sleep hours or arguments with friends and relatives, to quote but two.

\section{Keywords PSYCHOMETRICS, ADDICTION, SOCIAL MEDIA, HIGHER} EDUCATION, SCALE VALIDATION

\section{INTRODUCTION}

Technological developments in the mobile phone market took a giant leap forward when they placed intelligent telephones, or smartphones at everyone's disposal. This advance made it possible to have a fast and smooth Internet connection, facilitating access to social media, online gaming... The additional decrease in the prices of smartphones and connection costs has given rise to a situation where a large percentage of people of all ages (including children and adolescents) and from every social class, especially in developed countries, 
now own smartphones.

The use of these devices has led to an emerging behaviours that have gradually spread across the population, and which deserves to be studied because of their possible impacts, particularly in the case of youngsters and children.

Among such behaviours stands out a rise in such as the addiction to smartphones, social media or online gaming, together with a range of emerging and visible behaviours, among which the practice known as phubbing deserves a special mention. The portmanteau word phubbing results from blending the terms 'phone' and 'snubbing.' Phubbing, which consists in ignoring a person with whom you are having an interpersonal relationship to check your smartphone (Chotpitayasunondh \& Douglas, 2016; Karadağ et al., 2015; Roberts \& David, 2016), is a fairly recent phenomenon. Phubbing can be seen as inappropriate and improper behaviour by the person who is being ignored, and it is likewise widely regarded as disrespectful under usual social norms that require paying attention to an interlocutor during an interpersonal relationship with them. The intensity with which this practice is spreading along with its growing visibility has started to catch the eye of researchers in two dimensions: the person performing the behaviour in question; and the person who is at the receiving end of that behaviour. Nevertheless, what has raised greater interest is phubbing as such.

According to research studies, phubbing damages interpersonal relationships because it interferes in them (Erzen, Odaci, \& Yeniceri, 2019; Roberts \& David, 2017). This behaviour can show how people constantly change from engaging in phubbing to being at the receiving end of phubbing. For that reason, even though it may be socially accepted by many people, we should not overlook the fact that it can prove detrimental to interpersonal relationships, due to the emotions and reactions that it is likely to arouse in those who feel snubbed (Chotpitayasunondh \& Douglas, 2016).

Smartphones enable partners to have a greater communication, to be continually connected and to share experiences, images and information. Phubbing affects partner relationships and is considered a risk factor for their stability, as it generates feelings of ignorance, disrespect, dissatisfaction and contempt; it can additionally lead to conflict and acts of retaliation, revenge or even break-up by the person who is at the receiving end (Alvídrez \& Rojas-Solís, 2017; Roberts \& David, 2016; Wang, Xie, Wang, Wang, \& Lei, 2017).

In work relationships, phubbing by supervisors, managers or bosses while interacting with their subordinates, diminishes employees' trust and participation, and can eventually undermine work-related results (Roberts \& David, 2017).

For their part, Karadağ et al. (2016) claimed that phubbing has a negative effect not only on interpersonal relationships but also on the understanding of the conversation in which the interlocutors are supposedly engaged.

In the light of the effects caused by phubbing and bearing in mind that people always have their smartphones on them, it seems necessary to look into how this behaviour should be addressed. For this purpose, Roberts and David (2017) suggest establishing phone-free zones or negotiating with the people that we frequently interact with (family, friends, colleagues...) as to when it is appropriate to use a smartphone. In the same vein, Schneider 
and Hitzfeld (2019) believe that the use of a smartphone needs to be negotiated because certain difficulties seemingly appear when it comes to distinguishing between appropriate and inappropriate behaviour(s). Since the person who receives a message or call is also under pressure from the person on the other end of the line or the one who is waiting for a reply, to the extent that not replying may also be considered a sign of disrespect, this entails agreeing on the specific social situations in which someone can be connected (without being impolite).

The relationship between phubbing and Internet addiction has also raised interest, different studies having associated an addictive or problematic use of Internet with phubbing (Chotpitayasunondh \& Douglas, 2016; Davey et al., 2018; Karadag et al., 2015; T’ng et al., 2018) (Chotpitayasunondh \& Douglas, 2016; Davey et al., 2018; Karadağ et al., 2015; T’ng, Ho, \& Low, 2018).

Phubbing is also related to two other conducts that, in turn, are highly interrelated: being permanently online and permanently connected, or POPC; and the fear of missing out, or FOMO. Both behaviours contribute to the emergence of phubbing and are linked with certain personal issues that will be described below. Fear of missing out (FOMO) likewise has to do with the addiction to social media, and predicts and contributes to phubbing behaviour (Balta, Emirtekin, Kircaburun, \& Griffiths, 2020; Blanca \& Bendayan, 2018; Davey et al., 2018). Being permanently connected (POPC) has a bearing on the emergence of phubbing too (Schneider \& Hitzfeld, 2019).

With regard to some alterations that may come about due to phubbing, the latter has been associated with episodes of anxiety (Balta et al., 2020), depression (Wang et al., 2017) and a combination of both (Davey et al., 2018; González, Segura, \& Urbistondo, 2018; Roberts \& David, 2016).

Likewise, it has been concluded that people with more self-control practice phubbing to a lesser extent (Álvarez Menéndez \& Moral-Jiménez, 2020; Schneider \& Hitzfeld, 2019). Lastly, it is worth pointing out that people who feel socially excluded tend to practice phubbing more often, which actually worsens their situation, as it negatively impacts on their interpersonal relationships (David \& Roberts, 2017).

Numerous instruments have been designed to evaluate the problematic use of mobile phones. Simó, Martínez, Ballester, and Domínguez (2017) found 20 scales with good validity coefficients, and almost all of them were put together prior to the existence defining the concept of phubbing. However, they only found the scale prepared by Beranuy, Chamarro, Graner, and Carbonell (2009) and that of Matas-Terron (2015) in Spanish. In any case, only very few instruments have been validated to measure the phubbing phenomenon in Spanish.

Amongst the instruments used to measure phubbing stand out the following: Karadağ et al. (2015) measured phubbing by combining a range of scales (mobile phone use addiction, Internet addiction, addiction to social media, addiction to SMS and gambling addiction) as well as the phubbing scale. All of those scales have few items, with short, very direct questions. As for the Phubbing Scale, it has ten items which equitably correspond to two factors (five for each factor): communication disturbance; and mobile phone obsession. 
Blanca and Bendayan (2018) made an adaptation into Spanish of the Phubbing Scale (PS) developed by Karadağ et al. (2015) which they applied to a sample of 18-to-68-yearold Spaniards.

With the aim of establishing the relationship between FOMO and phubbing, Balta et al. (2020) used a combination of FOMO scales, the phubbing scale by Karadağ et al. (2015), and a neuroticism subscale, as well as a social media use questionnaire. To study this relationship, Schneider and Hitzfeld (2019) showed the participants a document about smartphone use and asked them to describe the last meal they had had with a friend. They also utilised an instrument meant to assess the perception of appropriate behaviour with a smartphone, a scale for measuring FOMO and another one that measured the situation of permanently being connected (POPC).

Roberts and David (2016) created a scale to measure the impact of phubbing on partner relationships which they applied and validated with an American sample. The scale has 9 items, including the place where smartphones are kept, at which moments and in which situations people look at them (during meals, during leisure time spent together, while talking...). Their findings clearly suggested that phubbing had a negative effect on partner relationships. Later, González et al. (2018) studied the psychometric properties of that scale and validated it with a sample in Puerto Rico. The results also revealed a negative influence of phubbing on partner relationships, although, unlike the study carried out in the USA, these researchers checked that women reported more cases of phubbing with the conflicts that it created in the relationship with their partners. In Portugal, Água, Lourenço, Patrão, and Leal (2019) also used the same scale and demonstrated the negative impact of phubbing on partner relationships, validating its use with a Portuguese sample. In contrast, Cizmeci (2017) applied the scale in a Turkish sample and affirmed its validity but the results did not reflect any negative influence. Nevertheless, Cizmeci believes that the status of marriage as a sacred union could have influenced the participants, as they may not have wanted not to reveal any problems in their partner relationships.

Chotpitayasunondh and Douglas (2016) prepared a Generic Scale of Phubbing (GSP) with fifteen items and four factors (nomophobia; personal conflict; self-isolation; and problem acknowledgement).

The effect caused by phubbing on the ignored person has hardly ever been measured, although attention was paid to this aspect in the Generic Scale of Being Phubbed (GSBP) prepared by Chotpitayasunondh and Douglas (2018), which has 22 items and three factors, namely: perceived norms of being phubbed; feeling ignored by others' phone use; and interpersonal conflict.

Analysing the phubbing scales allows us to see that they have few items, and also that the existing studies have tended to use a combination with other scales or questions related to a problematic use of smartphones, different addictions and social media.

The objective sought with this study consists in analysing the structural validity and reliability of a scale within a sample of Peruvian university students in Peru. Likewise, the study aims to improve the scale using the results of the initial validation, if possible. Lastly, we endeavoured to identify phubbing profiles amongst participants. 


\section{MATERIAL AND METHODS}

\subsection{Design and Sample}

This study was based a typical survey design, in a non-random sample. To this effect, a convenience sample of 454 students from nine universities located in northern Peru was used. Out of this number, 50.4\% were from Universidad Santo Toribio de Mogrovejo - USAT, 17\% belonged to Universidad Señor de Sipán, and 12.6\% were enrolled in Universidad Nacional Pedro Ruiz Gallo. The remaining participants were from Universidad Alas Peruanas - UAP (2.2\%), Universidad César Vallejo (5.9\%), Universidad Los Ángeles Chiclayo - ULADECH (0.7\%), Universidad Tecnológica de Perú - UTP (2.2\%), Universidad de Chiclayo - UDCH (4.4\%) and Universidad San Martín de Porres - USMP (4.6\%). The median sample age was 19 years old (interquartile range $=2.5$ ). Class marks were used to estimate the average age in years, which was 19.7 (s.d. $=2.79$ ). The proportion of women was $53.1 \%$ (i.e. $46.9 \%$ were men).

\subsection{Instruments}

Very few validated scales for measuring phubbing exist, and even fewer have been designed for a Spanish-speaking population. Although two scales collected in the reviewed literature were adapted into Spanish (one on phubbing and another one which revolves around phubbing and partner relationships), the situation requires a short instrument previously validated with a broad sample which is sensitive to the presence of this problem.

The scale put forward by Obregón (2015) met these requirements: it was short, adapted to the Spanish spoken in the Americas, and it had been applied in a population with social and cultural characteristics that resembled to a greater extent than other scales those of the population under study in our work. This scale, much like other validated scales, also has items related to the use of smartphones and social media. However, it was not validated and therefore needed to undergo a psychometric validation with a broad Spanish-speaking sample. At this point, it is important to emphasise that one of the basic criteria followed when selecting this instrument was that it had been written in Latin American Spanish, which enabled maximum contextualisation (García, 1993).

The scale is made up of 18 items in which people are asked about the time they spend connected to the Internet on their mobile phones, and about what they do (Obregón, 2015). The scores on this scale varied from 1 (never) to 4 (always).

The structural integrity of the scale was respected, with the different items implemented in an online survey system (LimeSurvey $\mathrm{GmbH}$ ), and adding the basic socio-demographic questions that the respective universities allowed: categorised age; sex; and university.

\subsection{Procedure}

A research collaborator qualified for the task administered the instrument to the participants via the Internet. The LimeSurvey software served to compile data. All the participants were informed that their participation was voluntary and that their personal information would be processed in keeping with the current regulations. 
After obtaining their informed consent, the participants were told to respond honestly. The collaborator in this research study provided any help necessary for them to be able to complete the survey correctly. All the data were compiled over the months of June and July 2019.

After verifying that the sample size met the proportion of five participants per item (Kass \& Tinsley, 1979) and over 150 cases (Pallant, 2021), the component axis was factored using varimax rotation. Three criteria were required to extract the factors: scree plot inflection; an eigenvalue higher than 1.0; and variance higher than $10 \%$. These methods provide results that can be generalised and reproduced, without inflating the variance estimates (Costello \& Osborne, 2005). Scores below 0.40 were considered low (Hair, Andersen, Tatham, \& Black, 1998; Stevens, 1996) and thus removed from the tables to facilitate reading. It was not possible to administer another instrument to analyse convergence and divergence validity, due to problems found during the application of the instrument at the participating universities.

\subsection{Analysis}

Next, a confirmatory factor analysis was carried out based on the result of a previous exploratory analysis. A maximum likelihood estimation (MLM) followed, as it works correctly even in abnormal conditions (T. Brown, 2015).

The following goodness of fit indices were used: (1) Chi-square ratio - degree of freedom where a ratio lower than 3 is considered acceptable (M. A. Ruiz, Pardo, \& Martín, 2010); (2) comparative fit index - CFI obtained from a free distribution estimation, due to the ordinal scale of the observed variables with values over 0.95 indicating a good fit of the model ( $\mathrm{Hu}$ \& Bentler, 1999); (3) the root mean square error of approximation - RMSEA, for which values below 0.05 are ideal, and those between 0.05 and 0.08 represent a reasonable error of approximation to the population (M. W. Brown \& Kudeck, 1993); and (4) the standardised root mean square residual - SRMR, in which values below 0.08 indicate a good fit of the model (T. Brown, 2015; Schermelleh-Engel \& Moosbrugger, 2003).

Reliability was tested using Cronbach's alpha coefficient $(\alpha)$ and McDonald's omega coefficient $(\omega)$. At the end of the process, the scores for the scale's subscales were descriptively explored after a structural analysis.

Version R 3.6.1 (R Core Team, 2020) and version 24 of SPSS were utilised to carry out the analysis described above.

\section{RESULTS}

A principal component analysis (PCA) served to investigate the scale's internal structure. The Kaiser-Meyer-Olkin (KMO) test gave a value of 0.876 and Bartlett's sphericity test produced a Chi-square value $=1388.833$ (d.f. $=153 ; \mathrm{p}<.001$ ). These results indicate that the correlation matrix was not an identity matrix. Through this method, and according to the criteria of eigenvalue higher than 1.0 and scree-plot (Figure 1), four components were extracted which account for $56.3 \%$ of the variance (Table 1 ). 


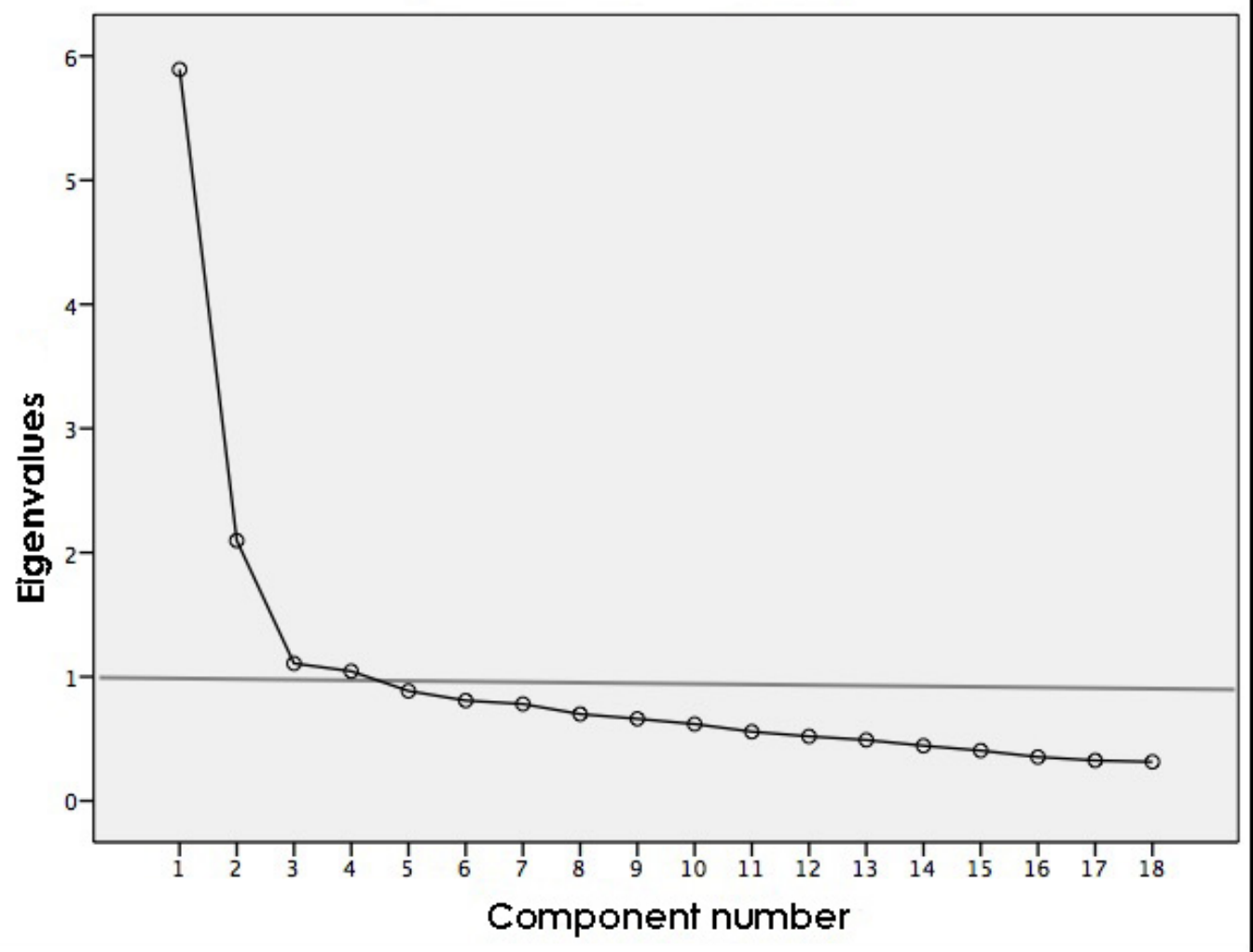

Figure 1 Scree-plot graphic. Source: own elaboration

In order to confirm the internal structure of the PCA, a confirmatory factor analysis (CFA) was carried out with a test subsample, obtaining the following fit indices (listed below): Chi-square $=222$; Chi-square - degree of freedom ratio $=1.72 ; \mathrm{CFI}=0.91$; RMSEA $=0.057$ (lower $=0.042$, upper $=0.069$ ); $\mathrm{SRMR}=0.070$; the Akaike information criterion $(\mathrm{AIC})=9003$; and the Bayesian information criterion $(\mathrm{BIC})=9027$. These results show a reasonable, good fit.

With this structure, Cronbach's $\alpha$ and McDonald's $\omega$ were 0.846 and 0.855 , respectively. If the v7 items are removed, the reliability would obtain an alpha value $=0.856$ and an $\omega=$ 0.861 . Furthermore, removing the $\mathrm{v} 3$ element would produce an alpha value of 0.858 and an $\omega$ of 0.864 .

Lastly, factor correlation (Table 2) is low but statistically significant.

Bearing in mind the previous results, the scale could be improved by removing elements v3 and v7, as well as the factors with less than three variables. The new scale is thus reduced to a one-dimensional instrument.

The CFA was performed once more for the one-dimensional structure after removing the indicated measures. The fit indices were as follows: Chi-square $=94.7$; Chi-square - degree of freedom ratio $=1.75 ; \mathrm{CFI}=0.95 ; \mathrm{RMSEA}=0.058$ (lower $=0.038$, upper $=0.077)$; $\mathrm{SRMR}$ $=0.041 ; \mathrm{AIC}=5898$; and $\mathrm{BIC}=6020$. These results show a better fit than the four-factor 
Table 1 Rotated Component Matrix

\begin{tabular}{lllll} 
& $(1)$ & $(2)$ & $(3)$ & $(4)$ \\
\hline v10 & .715 & & & \\
v13 & .712 & & & \\
v6 & .701 & & & \\
v16 & .687 & & & \\
v18 & .682 & & & \\
v11 & .633 & & & \\
v5 & .610 & & & \\
v14 & .582 & & & .423 \\
v9 & .578 & & & .441 \\
v4 & .561 & & & \\
v12 & .550 & & .471 & \\
v8 & .528 & & .409 & .350 \\
v7 & .338 & .752 & & \\
v1 & & .720 & & \\
v3 & & .710 & & \\
v17 & & & .717 & \\
v15 & & & .598 & \\
v2 & & & & .803 \\
Variance=56.33 & 28.80 & 10.63 & 8.91 & 7.99 \\
\hline
\end{tabular}

Table 2 Correlations between factors

\begin{tabular}{llllll} 
& F1 & F2 & F3 & F3 & F4 \\
\hline F1 & Pearson's r & - & & & \\
F2 & Pearson's r & $0.222^{* * *}$ & - & & \\
F3 & Pearson's r & $0.155^{*}$ & $0.237^{* * *}$ & - & \\
F4 & Pearson's r & $0.288^{* * *}$ & 0.124 & 0.117 & - \\
\hline
\end{tabular}

structure. Table 3 provides the estimated load for each item.

Table 4 includes the descriptors for the one-dimensional scale. This new structure gives the scale a Cronbach's alpha of 0.878 .

A one-way analysis of variance was applied to contrast different groups of participants (Figure 2). No differences appeared between men and women in the scale's global score $[F(1,449)=3.12, p=.078]$; nor were there differences between age groups $[F=(4,103)=1.93$, $\mathrm{p}=.112$ ]. By contrast, significant differences became visible between the universities of origin $[\mathrm{F}(8,33)=4.75, \mathrm{p}<.001]$, in relation to which the variance equality criterion was fulfilled using Levene's test $[\mathrm{F}(8,445)=1.54, \mathrm{p}=.141]$; however, this was not the case for normality $(\mathrm{W}=0.973 ; \mathrm{p}<.001)$.

The universities that achieved the highest average were Universidad Alas Peruanas (Filial Chiclayo) with a score of 2.33 (s.d.=0.244) and Universidad Los Ángeles de Chimbote (Filial Chiclayo) with an average score of 2.36 (s.d.=0.210), these two also being the universities with the fewest participants in this study. 
Table 3 Factor Loads

\begin{tabular}{|c|c|c|c|c|c|c|c|c|c|}
\hline \multirow{2}{*}{ Factor } & \multirow[b]{2}{*}{ Indicator } & \multirow[b]{2}{*}{ Estimate } & \multirow[b]{2}{*}{ SE } & \multicolumn{3}{|c|}{ 95\% Confidence Interval } & \multirow[b]{2}{*}{$\mathbf{p}$} & \multirow[b]{2}{*}{$\begin{array}{l}\text { Stand. } \\
\text { mate }\end{array}$} & \multirow[b]{2}{*}{ Esti- } \\
\hline & & & & Lower & Upper & $\mathbf{Z}$ & & & \\
\hline \multirow[t]{12}{*}{ Factor 1} & $\mathrm{v} 4$ & 0.382 & 0.0493 & 0.286 & 0.479 & 7.76 & $<.001$ & 0.516 & \\
\hline & v5 & 0.485 & 0.0540 & 0.379 & 0.591 & 8.98 & $<.001$ & 0.583 & \\
\hline & v6 & 0.497 & 0.0532 & 0.393 & 0.601 & 9.34 & $<.001$ & 0.603 & \\
\hline & v8 & 0.575 & 0.0549 & 0.467 & 0.683 & 10.47 & $<.001$ & 0.658 & \\
\hline & v9 & 0.689 & 0.0585 & 0.574 & 0.804 & 11.78 & $<.001$ & 0.721 & \\
\hline & v10 & 0.513 & 0.0544 & 0.407 & 0.620 & 9.44 & $<.001$ & 0.607 & \\
\hline & v11 & 0.529 & 0.0548 & 0.421 & 0.636 & 9.65 & $<.001$ & 0.618 & \\
\hline & v12 & 0.464 & 0.0579 & 0.350 & 0.577 & 8.01 & $<.001$ & 0.530 & \\
\hline & v13 & 0.626 & 0.0577 & 0.513 & 0.739 & 10.85 & $<.001$ & 0.677 & \\
\hline & v14 & 0.545 & 0.0503 & 0.446 & 0.643 & 10.84 & $<.001$ & 0.676 & \\
\hline & v16 & 0.495 & 0.0498 & 0.397 & 0.592 & 9.92 & $<.001$ & 0.632 & \\
\hline & v18 & 0.442 & 0.0557 & 0.333 & 0.551 & 7.93 & $<.001$ & 0.524 & \\
\hline
\end{tabular}

Table 4 Descriptive statistics of the items and reliability if they are removed

\begin{tabular}{lllll} 
& & \multicolumn{3}{c}{ If the item is dropped } \\
& Average & T.D. & Cronbach's $\alpha$ & McDonald's $\omega$ \\
\hline v4 & 1.84 & 0.743 & 0.873 & 0.874 \\
v5 & 1.99 & 0.834 & 0.870 & 0.870 \\
v6 & 1.74 & 0.827 & 0.869 & 0.869 \\
v8 & 2.08 & 0.875 & 0.866 & 0.867 \\
v9 & 1.85 & 0.958 & 0.863 & 0.864 \\
v10 & 2.00 & 0.847 & 0.869 & 0.864 \\
v11 & 2.10 & 0.858 & 0.868 & 0.869 \\
v12 & 2.16 & 0.878 & 0.873 & 0.873 \\
v13 & 1.69 & 0.927 & 0.865 & 0.866 \\
v14 & 1.63 & 0.807 & 0.866 & 0.866 \\
v16 & 1.81 & 0.784 & 0.868 & 0.869 \\
v18 & 1.90 & 0.845 & 0.873 & 0.874 \\
\hline
\end{tabular}

Smartphones are widely used by students to communicate with friends and family. The highest percentage of responses corresponds to the "always" option, with 39.4\%, a figure which rises to $74.6 \%$ if we add the percentage given for the "almost always" option.

According to $4 \%$ of students, their academic activity always suffers because of the time they spend on their smartphone, $15.9 \%$ of them admitting that this happens almost always.

$4.2 \%$ of students report that the people around them always reprimand them for spending too much time on their smartphone, and $17.4 \%$ say that this happens almost always.

As regards social media and their use on smartphones, we can highlight the following findings: 


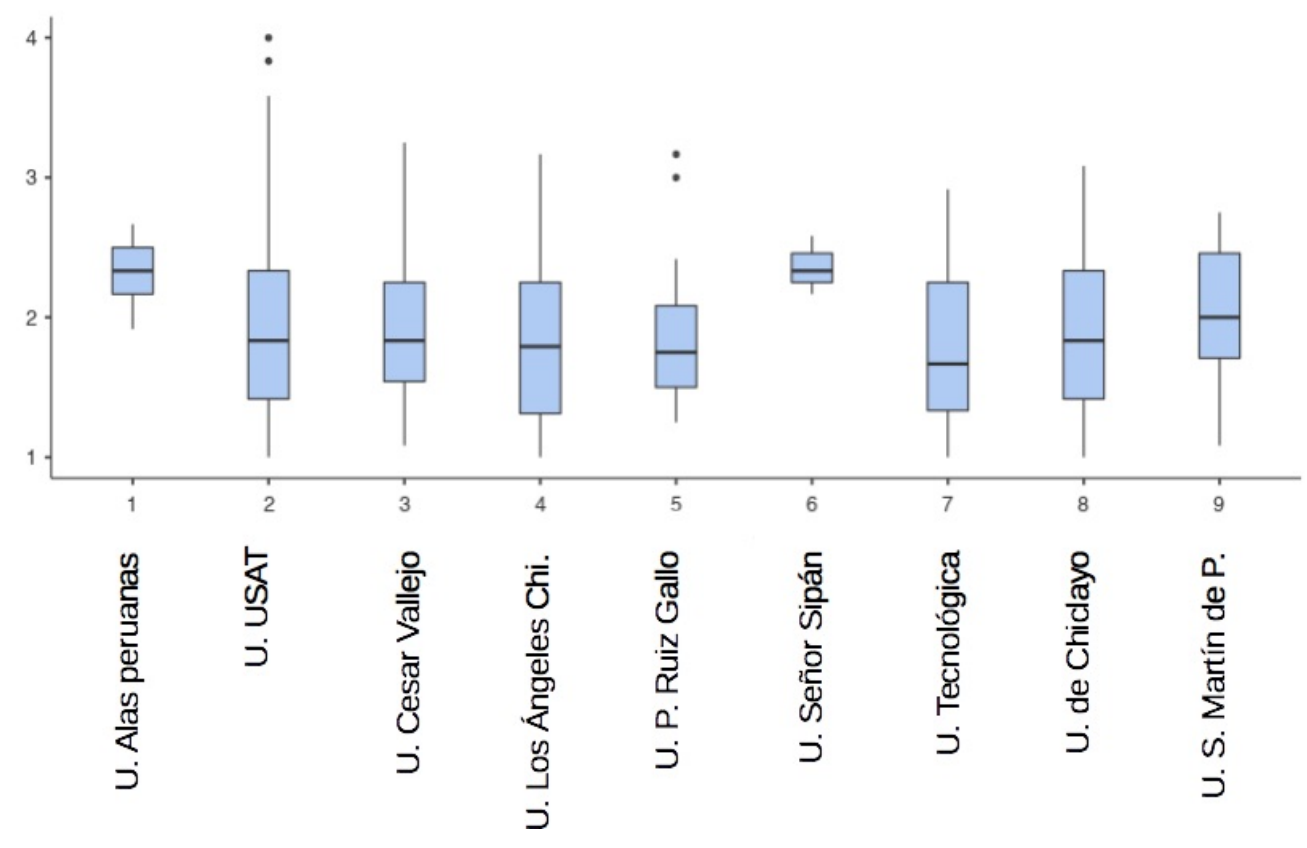

Figure 2 Box plot of universities

1. $38.8 \%$ claim that they almost always spend all their time checking their social media accounts on their smartphones, and $12.6 \%$ say that they do so always.

2. Even when they have more pressing tasks to deal with, $13.4 \%$ of the sample always prefer to check their social media first, and $32.2 \%$ do this almost always.

3. $7 \%$ of students lose sleep because they are checking their social media on their smartphone, and $13.4 \%$ claim that this happens almost always. Another $7.7 \%$ declare that they always try to spend less time checking their social media on their smartphones, but they have yet to achieve this. The percentage of students who report that they almost always have this same situation reaches $21.6 \%$.

4. According to students, when they are themselves in a social gathering with friends, everyone there always (13.2\%) or almost always (33.7\%) checks their social media on their smartphones. $4.4 \%$ of students claim that when they go out with their family, they always spend more time checking their social media than talking to their relatives, and $13.7 \%$ say that they do this almost always. On the other end of the scale, $38.1 \%$ state that they never do this.

$5.9 \%$ of students claim that they always ignore people to check their phone (phubbing); and $13 \%$ say they do so almost always. $66.1 \%$ engage in phubbing.

Phubbing in social gatherings with friends is carried out by $90.3 \%$ of the students surveyed. Phubbing is more prevalent when students meet their families: $61.9 \%$ claim to adopt this behaviour to a greater or lesser extent some time, with the percentage of those who do so always being situated at $4.4 \%$ and that of those resorting to phubbing almost always reaching 
$13.7 \%$.

$7.7 \%$ of the sample always ask for more time to check their smartphone when they are at social gatherings, and $21.6 \%$ do this almost always.

\section{DISCUSSION AND CONCLUSIONS}

To overcome the absence of psychometrically validated instruments to measure phubbing in young people in Peru, this study aimed to evaluate the psychometric characteristics of the scale elaborated by Costello and Osborne (2005). Considering that phubbing is a behaviour more typically shown by younger people (David \& Roberts, 2017; Schneider \& Hitzfeld, 2019), our research acquires greater relevance.

Moreover, the study presents a set of results regarding internal consistency and factor structure within a sample of young Peruvian university students. The principal component analysis showed a four-factor structure with an acceptable level of explained variance, which was consistent with the results of the confirmatory factor analysis. However, a onedimensional model offered greater fit indices in this confirmatory analysis. Using a modified 12-item scale is suggested for this purpose.

As regards gender, research has found that women engage more often in phubbing than men (Balta et al., 2020; Blachnio \& Przepiórka, 2018; T’ng et al., 2018). This happens because men have more face-to-face relationships than women, whereas the latter connect to a greater extent on their smartphones for social interaction purposes (David \& Roberts, 2017). Apart from women's social use, males see smartphones as empowering devices and take an interest in their instrumental functions (Chotpitayasunondh \& Douglas, 2016). Lastly, Karadağ et al. (2015) associate the problematic use of smartphones and social media as the greatest reason for phubbing in females, that status corresponding to Internet use and gaming amongst their male counterparts. Only one study shows a greater prevalence of phubbing in men: that performed by Villafuerte-Garzón and Vera-Perea (2018) which is particularly relevant for this research because it was carried out with students, teachers and administrative staff from an educational institution in Ecuador, and ours was undertaken in northern Peru, in an area close to the border with Ecuador. In our case, no significant differences between men and women surfaced in relation as regards the practice of phubbing.

Researchers have been looking into the psychological need to use a mobile phone since the last decade. The excessive of these types of devices has resulted in what is referred to as conflictive use and addictive dependence on mobile phones (Cambra, Díaz, Martínez, \& González, 2020). The incorporation of a built-in Internet connection and many more apps into the so-called smartphones has made their use even more appealing (J. Ruiz, Sánchez, \& Trujillo, 2016). Research carried out in different countries and cultures has shown that this excessive use of smartphones or the addiction to them is predictive of phubbing (Álvarez Menéndez \& Moral-Jiménez, 2020; Blachnio \& Przepiórka, 2018; Chotpitayasunondh \& Douglas, 2016; Davey et al., 2018; Karadağ et al., 2015). Roughly 5\% of the students involved in our study admit that they always use their smartphones at all times, and also that this 
makes it harder for them to fulfil their academic activities and social duties; the percentage of students who almost always have problems due to their smartphone use lies around 15\%. These percentages resemble those of the participants who claim that they are always phubbing (5.9\%) and those of the ones who engage in phubbing almost always $-13 \%$. Thus, a problematic use of smartphones could seemingly be a factor that predicts phubbing. Likewise, the results obtained match those obtained by Osborne (2015) in her study. This author found that $47 \%$ of her sample neglected their work duties, $5 \%$ was reprimanded, and $15 \%$ always or almost always lost sleep. In any case, the comparability of the results between both studies is limited due to the different procedures implemented.

It is important to bear in mind the importance of social media and their global nature, which have not only brought major advantages but also strengthened communication between people. However, the problematic use of social media or the addiction to them has prompted researchers to study the relationship between social media use and phubbing. Compulsive social media use was found to be a predictor of phubbing, since it leads to an increased snubbing behaviour where one permanently chooses to check out the latest on social media (Álvarez Menéndez \& Moral-Jiménez, 2020; David \& Roberts, 2017; Karadağ et al., 2015). There have also been studies focused on specific social media - Instagram (Balta et al., 2020) and Facebook (Bendayan \& Blanca, 2019; Blachnio \& Przepiórka, 2018) - and on how their problematic use and the addiction to them can act as a base to engage in phubbing. In our study, about $7 \%$ of students claim to always have problems because of the way in which they use social media, e.g. instance, losing sleep and prioritising social media over other more relevant tasks. That percentage is more than twice as high for those admitting that they almost always have problems. $18.1 \%$ of participants always, or almost always, engage in phubbing within the context of their family relationships to that they can check out social media on their smartphones, and this situation causes them problems and leads to criticism. These results are in keeping with those obtained by other studies mentioned in this paragraph.

Interestingly, engaging in phubbing during of gatherings with friends to check out social media seems to be become a consolidated habit, as $90.3 \%$ claim that everyone present in such gatherings does the same. Therefore, a certaindegree of) tacit agreement apparently exists in these gatherings to accept foregoing an interpersonal relationship in favour of checking out social media. These data give relevance to the studies carried out by David and Roberts (2017) and by Schneider and Hitzfeld (2019), supporting their proposals about the convenience of negotiating when it is appropriate to use a smartphone. Phubbing undoubtedly affects the quality of these relationships. We would also like to highlight that, even though students' phubbing has become widespread, this does not mean that the person on the receiving end of phubbing feels comfortable with the situation. In fact, only $9.3 \%$ of students express that they never feel uncomfortable when they are in a relationship and some friends of theirs do not pay attention to them because they are checking their smartphone.

In general, the results show that the scale has suitable psychometric properties which permit to evaluate phubbing in Peruvian young people. One of its main advantages lies in the fact that a one-dimensional measurement offers a score unaffected by other constructs. 
Likewise, the scale improves when certain items are removed, leaving 12 items instead of the initial 18.

Nevertheless, this study actually had to face certain limitations, the most important one being that the choice is not random. That circumstance largely restricts the possibility of generalising the results obtained. Research with samples from other regions and sociocultural levels becomes necessary as well. Another aspect worthy of mention is the need for replications that include other instruments to ensure concurrent validation. Lastly, attention must be paid to the social desirability of a sample in which some members may have faked their responses about their behaviour.

In any case, this study provides evidence about the scale's psychometric properties through its use with a sample of young university students in Peru. The factor structure is one-dimensional. The evidence also show not only that a significant percentage of students systematically engage in phubbing but also that such behaviour causes them problems in different areas of their social life, with social media use appearing as a strong motive for phubbing.

\section{REFERENCES}

Água, J., Lourenço, M. G., Patrão, I., \& Leal, I. (2019). Partner Phubbing: Portuguese Validation. Psicologia, Saúde \& Doença, 20(1), 234-241. https://doi.org/10.15309/19psd200119

Álvarez Menéndez, M., \& Moral-Jiménez, M. V. (2020). Phubbing, uso problemático de teléfonos móviles y de redes sociales en adolescentes y déficits en autocontrol. Health and Addictions/Salud y Drogas, 20, 113-125. https://doi.org/10.21134/haaj.v20i1.487

Alvídrez, S., \& Rojas-Solís, J. L. (2017). Los amantes en la época del smartphone: aspectos comunicativos y psicológicos relativos al inicio y mantenimiento de la relación romántica. Global Media Journal, 14(27), 1-18. https://doi.org/10.29105/gmjmx14.27-1

Balta, S., Emirtekin, E., Kircaburun, K., \& Griffiths, M. D. (2020). Neuroticism, trait fear of missing out, and phubbing: The mediating role of state fear of missing out and problematic Instagram use. International Journal of Mental Health and Addiction, 18, 628-639. https://doi.org/10 .1007/s11469-018-9959-8

Bendayan, R., \& Blanca, M. J. (2019). Spanish version of the Facebook intrusion questionnaire (FIQ-S). Psicothema, 31(2), 204-219. https://doi.org/10.1037/t77648-000

Beranuy, M., Chamarro, A., Graner, C., \& Carbonell, X. (2009). Validación de dos escalas breves para evaluar la adicción a Internet y el abuso de móvil. Psicothema, 21(3), 480-485.

Blachnio, A., \& Przepiórka, A. (2018). Be aware! If you start using Facebook problematically you will feel lonely: Phubbing, loneliness, self-esteem, and Facebook intrusion. A cross-sectional study. Social Science Computer Review, 37, 270-278.

Blanca, M., \& Bendayan, R. (2018). Spanish version of the phubbing scale: Internet addiction, Facebook intrusion, and fear of missing out as correlates. Psicothema, 30(4), 449-454.

Brown, M. W., \& Kudeck, R. (1993). Alternative ways of assessing model fit. Testing structural equation models (pp. 136-162). Sage.

Brown, T. (2015). Confirmatory factor analysis for applied research. Guilford.

Cambra, U. C., Díaz, V. C., Martínez, L. M., \& González, J. I. N. (2020). Smartphone: en comunicación, algo más que una adicción. Revista Latina de Comunicacion Social (RLCS), 75(75), 367-381. https://doi.org/10.4185/rlcs-2020-1431 
Chotpitayasunondh, V., \& Douglas, K. M. (2016). How "phubbing” becomes the norm: The antecedents and consequences of snubbing via smartphone. Computers in Human Behavior, 63, 9-18. https://doi.org/10.1016/j.chb.2016.05.018

Chotpitayasunondh, V., \& Douglas, K. M. (2018). Measuring phone snubbing behavior: Development and validation of the Generic Scale of Phubbing (GSP) and the Generic Scale of Being Phubbed (GSBP). Computers in Human Behavior, 88, 5-17. https://doi.org/10.1016/ j.chb.2018.06.020

Cizmeci, E. (2017). Disconnected, though satisfied: Phubbing behavior and relationship satisfaction. The Turkish Online Journal of Design, Art and Communication, 7(2), 364-375. https://doi.org/ 10.7456/10702100/018

Costello, A. B., \& Osborne, J. (2005). Best practices in exploratory factor analysis: Four recommendations for getting the most from your analysis. Practical Assessment, Research \& Evaluation, 10(7), 1-9.

Davey, S., Davey, A., Raghav, S. K., Singh, J. V., Singh, N., Błachnio, A., \& Przepiórkaa, A. (2018). Predictors and consequences of "Phubbing" among adolescents and youth in India: An impact evaluation study. Journal of Family \& Community Medicine, 25, 35-42.

David, M. E., \& Roberts, J. A. (2017). Phubbed and Alone: Phone Snubbing, Social Exclusion, and Attachment to Social Media. Journal of the Association for Consumer Research, 2(2), 155-163. https://doi.org/10.1086/690940

Erzen, E., Odaci, H., \& Yeniceri, I. (2019). Phubbing: Which personality traits are prone to phubbing? Social Science Computer Review, 19(2), 127-152. https://doi.org/10.1177/ 0894439319847415

García, C. (1993). Making a request and responding to it: a case study of Peruvian Spanish speakers. Journal of Pragmatics, 19(2), 90085-90089. https://doi.org/10.1016/0378-2166(93)90085-4

González, J. A., Segura, L. M., \& Urbistondo, V. (2018). Phubbing en las relaciones románticas: uso del celular, satisfacción psicológica y salud mental. Interacciones. Revista de Avances en Psicología, 4, 81-91.

Hair, J. F., Andersen, R. E., Tatham, R. L., \& Black, W. C. (1998). Multivariate data analysis (5th ed.). Prentice Hall.

Hu, L. T., \& Bentler, P. M. (1999). Cutoff criteria for fit indexes in covariance structure analysis: Conventional criteria versus new alternatives. Structural Equation Modeling: A Multidisciplinary Journal, 6(1), 1-55. https://doi.org/10.1080/10705519909540118

Karadağ, E., Tosuntaş, Ş. B., Erzen, E., Duru, P., Bostan, N., Şahin, B. M., ... Babadağ, B. (2015). Determinants of phubbing, which is the sum of many virtual addictions: A structural equation model. Journal of Behavioral Addictions, 4(2), 60-74. https://doi.org/10.1556/2006.4.2015 .005

Karadağ, E., Tosuntaş, Ş. B., Erzen, E., Duru, P., Bostan, N., Şahin, B. M., ... Babadağ, B. (2016). The Virtual World's Current Addiction: Phubbing. Addicta: The Turkish Journal on Addictions, 3(2), 250-269. https://doi.org/10.15805/addicta.2016.3.0013

Kass, R. A., \& Tinsley, H. E. A. (1979). Factor Analysis. Journal of Leisure Research, 11(2), 120-138. https://doi.org/10.1080/00222216.1979.11969385

LimeSurvey GmbH. (n/d). LimeSurvey: An Open Source survey tool/LimeSurvey GmbH. Retrieved from http://www.limesurvey.org

Matas-Terron, A. (2015). Encuesta sobre adicción a internet de Orman: un estudio psicometrico preliminar en una muestra universitaria de Andalucia. Universitas Psychologica, 14(3), 11071107.

Obregón, M. P. (2015). Phubbing y las relaciones interpersonales en adolescentes. Universidad Rafael Landívar. 
Pallant, J. (2021). SPSS survival manual: a step by step guide to data analysis using SPSS. Open University Press/McGraw-Hill. https://doi.org/10.4324/9781003117452

R Core Team. (2020). R: A language and environment for statistical computing. $R$ Foundation for Statistical Computing. Retrieved from https://www.R-project.org/

Roberts, J. A., \& David, M. E. (2016). My life has become a major distraction from my cell phone: Partner phubbing and relationship satisfaction among romantic partners. Computers in Human Behavior, 54, 134-141. https://doi.org/10.1016/j.chb.2015.07.058

Roberts, J. A., \& David, M. E. (2017). Put down your phone and listen to me: How boss phubbing undermines the psychological conditions necessary for employee engagement. Computers in Human Behavior, 75, 206-217. https://doi.org/10.1016/j.chb.2017.05.021

Ruiz, J., Sánchez, J., \& Trujillo, J. M. (2016). Using Internet and dependence on mobile phones in adolescents. Revista Latinoamericana de Ciencias Sociales, 14, 1357-1369.

Ruiz, M. A., Pardo, A., \& Martín, R. S. (2010). Modelos de ecuaciones estructurales. Papeles del Psicólogo, 3(1), 34-45.

Schermelleh-Engel, K., \& Moosbrugger, H. (2003). Evaluating the Fit of Structural Equation Models: Tests of Significance and Descriptive Goodness-of-Fit Measures. Methods of Psychological Research Online, 8(2), 23-74.

Schneider, F. M., \& Hitzfeld, S. (2019). I Ought to Put Down That Phone but I Phub Nevertheless: Examining the Predictors of Phubbing Behavior. Social Science Computer Review, 089443931988236-089443931988236. https://doi.org/10.1177/0894439319882365

Simó, C., Martínez, A., Ballester, M. L., \& Domínguez, A. (2017). Instrumentos de evaluación del uso problemático del teléfono móvil/Smartphone. Health and Addictions, 17(1), 5-14. https://doi.org/10.21134/haaj.v17i1.265

Stevens, J. (1996). Applied multivariate statistics for the social sciences (3rd ed.). Lawrence Erlbaum Associates.

T’ng, S., Ho, K. H., \& Low, S. K. (2018). Are you "phubbing" me? The determinants of phubbing behavior and assessment of measurement invariance across sex differences. International and Multidisciplinary Journal of Social Sciences, 7(2), 159-190. https://doi.org/10.17583/rimcis .2018 .3318

Villafuerte-Garzón, C. M., \& Vera-Perea, M. (2018). Phubbing y género en un sector académico en Quito: Uso, abuso e interferencia de la tecnología. Convergencia Revista de Ciencias Sociales, 79(79), 01-01. https://doi.org/10.29101/crcs.v0i79.9156

Wang, X., Xie, X., Wang, Y., Wang, P., \& Lei, L. (2017). Partner phubbing and depression among married Chinese adults: The roles of relationship satisfaction and relationship length. Personality and Individual Differences, 110, 12-17. 